Indonesian Journal of Pharmaceutical Science and Technology Journal Homepage : http://jurnal.unpad.ac.id/ijpst/

\title{
Effect of Ethanol Concentration on Antibacterial Activity of Bligo Fruit Extract (Benincasa hispida Thunb) to Salmonella typhi
}

\author{
Fhahri Mubarak $^{1 *}$, Sartini Sartini², Dia Purnawanti ${ }^{1}$ \\ ${ }^{1}$ Sekolah Tinggi Ilmu Farmasi Makassar, Makassar, Indonesia \\ ${ }^{2}$ Universitas Hasanuddin Makassar, Makassar, Indonesia \\ Submitted 13 April 2018; Revised 14 May 2018; Accepted 15 May 2018; Published 01 October 2018 \\ *Corresponding author: fhahrimubarak@gmail.com
}

\begin{abstract}
Bligo fruit (Benincasa hispida Thunb) is one of medicinal plants used to cure typhoid fever which caused by Salmonella typhi bacteria. The aim of this research was to find out the effect of ethanol concentration as a solvent from Bligo fruit (Benincasa hispida Thunb) extracts as an antibacterial, especially to Salmonella typhi. This simplicia was being extracted with $96 \%$ ethanol, $70 \%$ ethanol, and $50 \%$ ethanol by using maceration method for $3 \times 24$ hours. The antibacterial activity test was done by diffusion of agar method to the MHA medium by obserring the resistor zone which formed from $96 \%$ ethanol, $70 \%$ ethanol and $50 \%$ ethanol. The diametres obtained were $6.815 \mathrm{~mm}$ for $96 \%$ ethanol, $25.223 \mathrm{~mm}$ for $70 \%$ ethanol while for $50 \%$ ethanol there was no resistance zone can be observed. From the result can be conclude that the best concentration of ethanol that has a great potencial as resistor to Salmonella typhi bacteria was the Bligo fruit (Benincasa hispida Thunb) extracts of $70 \%$ ethanol.
\end{abstract}

Keywords: Antibacterial, Benincasa hispida Thunb, bligo fruit, Salmonella typhi.

\section{Pengaruh Konsentrasi Etanol pada Aktivitas Antibakteri Ekstrak Buah Bligo (Benincasa hispida Thunb) terhadap Salmonella typhi}

\begin{abstract}
Abstrak
Buah Bligo (Benincasa hispida Thunb) merupakan salah satu tanaman obat tradisional yang digunakan untuk mengobati penyakit demam tifoid yang disebabkan oleh bakteri Salmonella typhi. Tujuan dari penelitian ini untuk mengetahui pengaruh konsentrasi etanol sebagai cairan penyari dari ekstrak Buah Bligo (Benincasa hispida Thunb) yang memberikan efek antibakteri, khususnya Salmonella typhi. Simplisia tersebut diekstraksi dengan etanol 96\%, etanol 70\% dan etanol 50\% menggunakan metode maserasi selama $3 \times 24$ jam. Uji aktivitas antibakteri dilakukan dengan metode difusi agar pada medium MHA dengan melihat zona hambat yang terbentuk dengan etanol $96 \%$, etanol $70 \%$ dan etanol $50 \%$ tersebut didapatkan diameter pada etanol 96\% diperoleh sebesar 6,815 mm, pada etanol 70\% diperoleh sebesar 25,223 mm dan pada etanol 50\% tidak terdapat zona hambat. Hasil penelitian dapat disimpulkan bahwa konsentrasi etanol sebagai cairan penyari dari ekstrak Buah Bligo (Benincasa hispida Thunb) yang memiliki daya hambat yang baik pada konsentrasi 10\% terhadap bakteri Salmonella typhi adalah etanol $70 \%$.
\end{abstract}

Kata Kunci: Antibakteri, Benincasa hispida Thunb, buah bligo, Salmonella typhi. 


\section{Pendahuluan}

Demam tifoid merupakan salah satu penyebab kematian utama di dunia dengan angka kematian sebesar 12,6 juta kasus dan diperkirakan terjadi 600.000 kematian tiap tahunnya. Hampir $80 \%$ dari kasus tersebut terjadi di Asia. ${ }^{1}$ Kejadian demam tifoid di Indonesia sekitar 1.100 kasus per 100.000 penduduk per tahunnya dengan angka kematian 3,1-10,4\%. ${ }^{2}$ Patogenesis pada Salmonella typhi diawali dengan adhesi pada permukaan usus, tahap selanjutnya adalah menembus lamina propia dalam usus dan terfagosit oleh makrofag. Salmoella yang terfagosit menyebar ke ileum bagian distal dan kolon. Dengan reseptor TLR-5 dan TLR-4 / MD2 / CD-14, makrofag mengenali pola molekul patogen terkait seperti flgela dan lipopolisakarida pada bakteri, sehingga makrofag dan sel epitel usus menarik sel T dan menimbulkan infeksi pada usus. ${ }^{3}$

Keragaman genetik dan fisiologis kehidupan mikroba sangat besar melebihi tanaman maupun hewan. Keragaman ini merupakan sumbangsi yang besar dari beberapa sifat mikroorganisme. ${ }^{4}$

Untuk infeksi S. typhi biasanya diobati dengan antibiotika seperti kloramfenikol, tiamfenikol, ampisilin, dan kotrimoksazol dengan indikasi penyembuhan atau penanganan penyakit seperti demam tifoid. Namun, penggunaan antibiotika yang tidak tepat dapat menimbulkan efek samping seperti resistensi terhadap antibiotika. Oleh karena itu, mulai dikembangkan penelitian untuk meminimalisir efek samping dari penggunaan antibiotika. ${ }^{5}$

Salah satu tanaman obat yang digunakan oleh masyarakat untuk mengobati demam tifoid yaitu bligo (Benincasa hispida Thunb).

Buah bligo mengandung minyak atsiri, flavanoid, glikosida, protein, vitamin, mineral, tanin, saponin, antrakuinon. ${ }^{6,7}$ Untuk mendapatkan senyawa tersebut perlu dilakukan ekstraksi.

Proses ekstraksi adalah proses perpindahan massa dari komponen zat padat yang terdapat pada simplisia ke dalam pelarut organik yang digunakan. Pelarut organik akan menembus dinding sel dan selanjutnya akan masuk ke dalam rongga sel tumbuhan yang mengandung zat aktif. Kemudian zat aktif akan terlarut dalam pelarut organik pada bagian luar sel untuk selanjutnya berdifusi masuk ke dalam pelarut. Proses ini terus berulang sampai terjadi keseimbangan konsentrasi zat aktif antara di dalam sel dan di luar sel. ${ }^{8}$

Penelitian sebelumnya telah dilakukan pengujian daya hambat terhadap $S$. typhi dengan menggunakan beberapa cairan penyari dan didapatkan ekstrak etanol memiliki aktivitas yang paling baik. ${ }^{9}$ Sehingga perlu dilakukan pengujian aktivitas daya hambat dari ekstrak buah bligo dengan beberapa konsentrasi etanol yaitu 96\%, 70\%, dan 50\%, untuk mengetahui apakah ekstrak buah bligo memiliki aktivitas terhadap bakteri $S$. typhi. Adapun tujuan penelitian ini untuk menentukan konsentrasi etanol terbaik sebagai cairan penyari dari ekstrak buah Bligo yang memberikan efek terhadap S. typhi. Sehingga diharapkan pada penelitian ini dapat memberikan informasi kepada masyarakat tentang aktivitas antibakteri ekstrak etanol buah bligo (B. hispida Thunb) terhadap bakteri $S$. typhi penyebab penyakit tifoid.

\section{Metode}

2.1. Alat

Alat-alat yang digunakan dalam penelitian ini antara lain yaitu autoklaf (Gea $\left.{ }^{\circledR}\right)$, batang pengaduk, bunsen, botol semprot, cawan petri (Pyrex $\left.{ }^{\circledR}\right)$, cawan porselin, Erlenmeyer (pyrex $\left.{ }^{\circledR}\right)$, gelas ukur (pyrex $\left.{ }^{\circledR}\right)$, gelas kimia (Pyrex $\left.{ }^{\circledR}\right)$, inkubator (Memmert ${ }^{\circledR}$ ), jangka sorong, mikropipet (Eppendrof $(\AA)$, oven (Falc $\AA)$, pinset, paper disk kosong, sendok tanduk, swab steril, vial, timbangan analitik (Mettler Toledo $($ ) ), tabung reaksi (Pyrex $\left.{ }^{\circledR}\right)$.

\subsection{Bahan}

Bahan yang digunakan dalam penelitian ini adalah Aluminium foil, Aquadest, bakteri S. typhi, Ekstrak buah bligo (B. hispida Thunb), Etanol 96\%, Etanol 70\%, Etanol $50 \%$, kapas, label, $\mathrm{NaCl}$ fisiologis $0,9 \%$, media MHA 


\subsection{Prosedur Rinci}

\subsubsection{Penyiapan Sampel}

Sampel penelitian yang akan digunakan diperoleh dari Kecamatan Pitumpanua, Kabupaten Wajo. Buah bligo (B. hispida Thunb) yang telah dipetik, selanjutnya dibersihkan dari benda-benda asing (debu) atau kotoran lainnya. Buah bligo yang telah dibersihkan selanjutnya dikupas dan kemudian dirajang untuk mempermudah proses pengeringan. Sampel buah bligo dikeringkan dengan menggunakan lemari pengering pada suhu $50^{\circ} \mathrm{C}$.

\subsubsection{Pembuatan Ekstrak}

Serbuk simplisia masing-masing sebanyak 200 g dimasukan kedalam bejana maserasi, kemudian dibasahi menggunakan pelarut etanol 96\%, 70\% dan 50\% sebanyak $500 \mathrm{ml}$ hingga serbuk simplisia terbasahi sempurna, diamkan selama 15-30 menit, ditutup dengan menggunakan alumunium foil, didiamkan selama 3 hari dan terlindung dari cahaya sambil sesekali diaduk, lalu disaring menggunakan kain flanel.

\subsubsection{Sterilisasi Alat}

Alat gelas yang digunakan dicuci dengan deterjen, kemudian dibilas dengan air suling lalu dikeringkan. Untuk alat-alat yang bersifat tahan panas dan tidak berskala seperti alat gelas disterilkan dengan menggunakan oven pada suhu $180^{\circ} \mathrm{C}$ selama 2-3 jam. Sedangkan alat-alat yang terbuat dari plastik dan berskala dapat disterilkan menggunakan autoklaf pada suhu $121^{\circ} \mathrm{C}$ selama 15 menit. Untuk ose disterilkan dengan cara dipijarkan dengan menggunakan lampu spiritus.

\subsubsection{Pembuatan Medium}

Mueller Hinton Agar (MHA) dilarutkan sebanyak 38 gram kedalam 1000 mL aquadest. Dipanaskan hingga mendidih menggunakan microwave, diaduk hingga homogen. Ditutup mulut erlenmeyer dengan kasa steril dan disterilkan dalam autoklaf pada suhu $121^{\circ} \mathrm{C}$ selama 15 menit. ${ }^{10}$

\subsubsection{Penyiapan Bakteri Uji}

Bakteri S. typhi diambil dengan menggunakan ose steril, selanjutnya diinokulasikan dalam medium MHA miring dengan cara digoreskan, setelah itu diinkubasi dalam inkubator selama 24 jam bakteri pada suhu $37^{\circ} \mathrm{C}$.

Bakteri uji yang telah diremajakan selama 18-24 jam, masing-masing diambil satu ose kemudian disuspensikan kedalam larutan $\mathrm{NaCl}$ fisiologis $0,9 \%$, setelah itu dihomogenkan. Suspensi diinkubasi selama 24 jam dan diukur serapannya dengan menggunakan spektrofotometer pada panjang gelombang $580 \mathrm{~nm}$ sehingga diperoleh transmitan $25 \%$, sebagai blanko di gunakan $\mathrm{NaCl} 0,9 \%$ steril, kekeruhannya diseragamkan dengan menggunakan standar Mc. Farland 0,5 (kepadatan bakteri 1,5 X 108).

\subsubsection{Uji Daya Hambat}

Uji ini dilakukan dengan menggunakan medium MHA yang dimasukkan ke dalam cawan petri sebanyak 10-15 mL, kemudian dipipet suspensi bakteri sebanyak $20 \mu 1$ lalu di homogenkan. Selanjutnya sampel uji dan kontrol negatif diteteskan sebanyak $20 \mu \mathrm{l}$ pada paperdisks lalu dibiarkan hingga menyerap. Setelah medium memadat, paperdisks dimasukkan kedalam cawan petri. Kemudian diinkubasi dalam inkubator selama 24 jam pada suhu $37^{\circ} \mathrm{C}$. Diamati dan diukur diameter hambat paper disk menggunakan jangka sorong.

\subsubsection{Pengumpulan Data}

Data yang dikumpulkan dari hasil pengujian ekstrak buah bligo terhadap bakteri uji $S$. typhi berupa hasil pengukuran diameter zona hambatan yang bersifat antibakteri.

\section{Hasil}

\subsection{Rendemen Ekstrak}

Pada tahap awal peneltian dilakukan ekstraksi sampel buah Bligo (B. hispida Thunb) dengan metode maserasi menggunakan beberapa penyari yaitu etanol $96 \%, 70 \%$ dan 50\% (Tabel 1). Hasil ekstrak kental yang diperoleh kemudian diuji aktivitas antibakterinya terhadap bakteri $S$. typhi untuk melihat besar daya hambat yang dapat diberikan. 
Tabel 1. Rendemen hasil ekstraksi

\begin{tabular}{cccc}
\hline Penyari & Simplisia & Ekstrak Kental & Rendemen \\
\hline Etano1 96\% & $200 \mathrm{~g}$ & $14,3567 \mathrm{~g}$ & $7,178 \%$ \\
Etano1 70\% & $200 \mathrm{~g}$ & $45,7448 \mathrm{~g}$ & $22,8724 \%$ \\
Etano1 50\% & $200 \mathrm{~g}$ & $50,5196 \mathrm{~g}$ & $25,2598 \%$ \\
\hline
\end{tabular}

\subsection{Uji Daya Hambat}

Ekstrak kental dari ke 3 konsentrasi penyari diujikan aktivitas antibakterinya terhadap bakteri S. typhi (Gambar 1). Untuk menguatkan hasil dilakukan 3 kali replikasi dengan tiap replikasi digunakan 3 konsentrasi penyari dan 1 sebagai kontrol.

Hasil pengujian daya hambat ekstrak buah Bligo (B. hispida Thunb) terhadap bakteri $S$. typhi dengan variasi konsentrasi penyari dan didapatkan bahwa ekstrak etanol $70 \%$ memiliki aktivitas zona hambat yang baik terlihat dari besar zona hambat yang dihasilkan (Tabel 2).

\section{Pembahasan}

Pada tahap awal peneltian dilakukan ekstraksi sampel buah Bligo (B. hispida Thunb) dengan metode maserasi menggunakan beberapa penyari yaitu etanol $96 \%, 70 \%$ dan $50 \%$.

Rendemen hasil ekstraksi dengan metode maserasi menggunakan etanol, menurut beberapa penelitian komponen zat aktif buah Bligo mengandung beberapa senyawa yang diduga sebagai minyak atsiri, flavanoid, glikosida, protein, vitamin, mineral, sedangkan menurut Musmuallim (2006) mengandung tanin, saponin, dan antrakuinon. ${ }^{7}$ Senyawa-senyawa tersebut ada yang bersifat polar dan non polar. Digunakan penyari ini dengan metode ekstraksi secara maserasi yaitu dengan melihat dari sifat zat aktif senyawa flavanoid yang akan ditarik yang tidak tahan terhadap panas. Penyari yang digunakan adalah etanol karena penyari ini dapat melarutkan hampir semua senyawasenyawa yang ada pada sampel, baik senyawa polar maupun non polar. Perbedaan kadar etanol 96\%, 70\% dan 50\%, mungkin akan ada perbedaan sedikit tingkat kepolarannya yaitu yang lebih non polar etanol $96 \%$ dan yang lebih polar etanol 50\%.

Pada uji bebas etanol ekstrak maserasi dilakukan dengan cara ekstrak ditambahkan dengan asam sulfat pekat dalam vial, kemudian ditambahkan dengan asam asetat lalu ditutup mulut vial dengan menggunakan kapas. Selanjutnya dipanaskan sampai mendidih, setelah itu diidentifikasi bau pada kapas, bila tidak ada bau ester berarti pada ekstrak sudah tidak terdapat etanol. Pengujian hasil antibakteri dari ekstrak buah bligo dilakukan terhadap bakteri $S$. typhi karena dari hasil pengalaman empiris bahwa ekstrak buah bligo ini biasa digunakan untuk mengobati penyakit demam tifoid, kemudian hasilnya dibuktikan melalui pengujian secara in vitro dengan metode difusi diperoleh hasil sebagai berikut dapat dilihat pada gambar 2 .
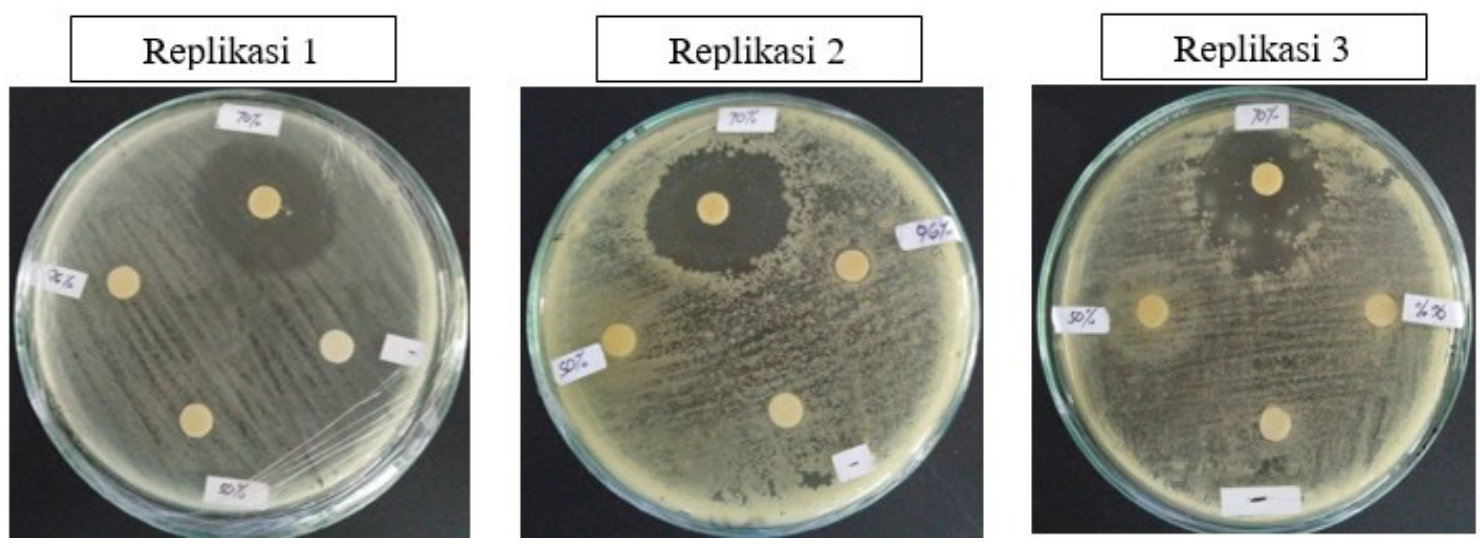

Gambar 1. Hasil uji daya hambat buah bligo (Benincasa hispida Thunb) 
Tabel 2. Diameter zona hambat ekstrak buah bligo

\begin{tabular}{cccc}
\hline Replikasi & \multicolumn{3}{c}{ Diameter Zona Hambat (mm) } \\
\cline { 2 - 4 } & $\mathbf{9 6 \%}$ & $\mathbf{7 0 \%}$ & $\mathbf{5 0 \%}$ \\
\hline I & 6,93 & 26 & 0 \\
II & 6,7 & 25 & 0 \\
III & 0 & 24,67 & 0 \\
Rata-rata & 6,815 & 25,223 & 0 \\
\hline
\end{tabular}

Penelitian ini dilakukan dengan tujuan untuk membedakan apakah ada pengaruh cairan penyari konsentrasi etanol sebagai cairan penyari, ekstrak yang diperoleh daya hambat dan ekstrak yang diperoleh ternyata terdapat pada ekstrak etanol $96 \%$ dan $70 \%$.

Pada ekstrak etanol 50\% lebih polar dibandingkan etanol $70 \%$ sedangkan etanol $70 \%$ lebih polar daripada $96 \%$. Ini menunjukkan bahwa zat yang bersifat antibakteri tidak dapat tertarik pada etanol 50\% dan sedikit tertarik pada etanol 96\%. Dan penarikan senyawa yang lebih baik terdapat pada etanol $70 \%$ sehingga yang memberikan daya hambat yang terbaik adalah etanol $70 \%$. Dari hasil pengujian daya hambat ekstrak buah Bligo (B. hispida Thunb) terhadap bakteri $S$. typhi didapatkan bahwa ekstrak etanol $70 \%$ memiliki aktivitas zona hambat yang baik sebesar 25,223 mm dibandingkan dengan ekstrak etanol $96 \%$ dan 50\%. Hal ini terjadi karena adanya tingkat kepolaran senyawa dan cairan penyari.

Pada penelitian lainnya telah dilakukan pengujian ekstrak buah Bligo dengan menggunakan 3 macam penyari, yaitu etanol, etil asetat dan n-heksan. Dari hasil penelitian tersebut didapatkan zona hambat yang besar pada penyari etanol $96 \% .{ }^{9}$ Berdasarkan penelitian tersebut, dilakukan pengujian dengan variasi konsentrasi penyari etanol yaitu etanol $96 \%$, etanol $70 \%$ dan etanol $50 \%$. Dengan tujuan untuk melihat daya hambat yang baik pada bakteri $S$. typhi.

\section{Simpulan}

Konsentrasi etanol sebagai cairan penyari dari ekstrak Buah Bligo (B. hispida Thunb) yang memiliki daya hambat yang baik pada konsentrasi $10 \%$ terhadap bakteri S. typhi adalah etanol $70 \%$.

\section{Daftar Pustaka}

1. Abro AH, Abdou AMS, Gangwani JL, Younis NJ, Hussaini HS. 2009. Hematological and biochemical changes in typhoid fever. Pak J Med Sci; 25(2): 166-171

2. Nasruddin, Hadi U, Vitanata, Erwin AT, Bramantono, Suharto. 2007. Penyakit infeksi diindonesia, Airlangga University Press ; Surabaya.

3. Raffatellu M. 2008. Clinical Pathogenesis of Typhoid Fever. J Infect Developing Countries, 2 (4), 260-266.

4. Madigan, Marthinko, Stahl, Clark. 2012. Biology of Microorganism. Pearson Education, Inc. San Franscisco.

5. Lecas L. 2010. Journal of American Medical Association, Antibiotic Resistance a Major Public Health Problem.

6. Esmail A. 2013. The Pharmacological Importace of Benincasa hispida. A review. Departemen of Pharmacology, Collage of Medicine, University Iraq. ISSN : $0975-$ 9492 Hal 165

7. Musmuallim.2006. Isolasi dan identifikasi komponen kimia buah bligo (Benincasa hispida) dalam ekstrak etanol, FMIPA; Surakarta.

8. Marjoni R, MP Sari, Y Lukmayani, L Syafnir. 2016. Isolasi dan Identifikasi Senyawa Flavonoid pada Tangkai Daun Tembakau (Nicotiana tabacum L). Proceeding of Pharmacy gel 2 Th Akad 2016-2017. SPeSIA . Unisba

9. Reski K. 2016. Uji Daya Hambat dan Analisis KLT-Bioautografi Ekstrak Etanol Buah Bligo (Benincasa hispida Thunb) Terhadap Bakteri Uji Salmonella typhi dan Staphylococcus aureus, STIFA Kebangsaan; Makassar. 
10. Oxoid. Muller Hinton Agar, (online) diakses 21 Juni 2017. http://www.oxoid. com 